\title{
The Influence of Capital Structure Towards Profitability of Fishery Companies Listed in Indonesia Stock Exchange
}

\author{
Siti Rochmah (Corresponding author) \\ Sekolah Tinggi Ilmu Ekonomi STIE Semarang, Indonesia \\ E-mail: siti.rochmah@stiesemarang.ac.id \\ Diah Yuliana \\ Sekolah Tinggi Ilmu Ekonomi STIE Semarang, Indonesia \\ Arini Novandalina \\ Sekolah Tinggi Ilmu Ekonomi STIE Semarang, Indonesia
}

Received: January 3, 2018

doi:10.5296/ijafr.v8i2.12414
Accepted: January 22, 2018 Published: April 25, 2018

URL: https://doi.org/10.5296/ijafr.v8i2.12414

\begin{abstract}
This study discuss the effect of capital structure on profitability at fishery companies listed on the BEI (2014-2016.). The research aims to Analyze the influence of capital structure of Debt to Equity Ratio (DER) to Return On Equity ROE) on Fishery Companies listed on the Stock Exchange. The population in this research are three fishery companies with capital structure and Profitability of fishery company listed in Indonesia Stock Exchange. Whereas the sample selection method used is Purposive Sampling. Based on the results of data analysis and discussion that has been described then the conclusions in this study are DER Ratio influencing the ROE of Fisheries Companies listed in Indonesia Stock Exchange period 2014 -2016. The hypothesis that there is a positive influence is rejected. Because the results of research on fishery companies turned out to show negative results.
\end{abstract}

Keywords: Capital structure, Profitability, Fishery, Indonesia Stock Exchange 


\section{Introduction}

Financial function is one of the important functions in the company activities. One of the elements is how company able to meet the needs of funds to operate and develop business. To meet the needs, the company can obtain from own capital or from outside the company. Principally, companies tend to use their own capital rather than foreign capital which is only used as a complement if the required funds are less sufficient. This is in accordance with an alternative theory of corporate financing decisions or known as Pecking Order Theory, companies tend to choose funding that comes from internal rather than external, then the recommended funding sequence is first retained earnings, then debt, and the last new equity issuance (Myers , 1997).

The problem of capital involves obtaining, providing or using capital that rewuired by the company in the most effective and efficient way. In other words, all this concerns the problem of financial structure and capital structure. Financial managers need to know the relationship between capital structure and firm value, where the two elements that make up the capital structure are the structure of wealth and financial structure. Structure of wealth according to Aurin Apriani (2001: 7) "Balance or comparison between current assets and fixed assets". Selection of financial structure according to Sawir (2005: 11) "The financial structure is a problem concerning the composition of funding that will be used by the company to fund its assets".

Financing companies must use permanent sources of funds derived from long-term debt and own capital, the two elements will form the capital structure. Sawir (2005) states that the capital structure is the composition of the sources of financing used by companies in the form of equations, then the relationship between the financial structure and capital structure is the financial structure minus the short-term debt will be equal to the capital structure. It can be concluded that the capital structure is the balance of all the long-term financing sources used for all corporate activities, the capital structure is part of the financial structure.

The analysis of financial ratios tries to connecting the balance sheet elements and profit-and-loss calculations to one another. It also could give an idea of the company's history and its current position assessment. Ratio analysis also enables financial managers to estimate the reaction of creditors and investors and provide an insight into how approximately funds can be obtained (Sawir, 2005). Analysis of financial ratios used is Profitability analysis called Return On Equity (ROE). Capital structure is one of the important decisions of financial managers in improving profitability for the company.

The source of funds should be efficient, it is expected that the company can increase its profits. According to Irawati (2006: 193) states that "The use of each type of capital has a different effect on the profits derived company". Meanwhile, according to Aditya (2006: 22) states that Companies with high profitability and greater use of Internal Financing can reduce the use of debt this opinion is the same with the opinion of Weston and Bringham (1994: 150) stating that companies that have high returns on investment tend to have small amounts of debt because of the use of equity is greater. Another opinion on this subject is Sartono (1996: 296) states that the greater the use of debt in the capital structure the more the Return On 


\section{Mll Macrothink}

International Journal of Accounting and Financial Reporting

ISSN 2162-3082

2018, Vol. 8, No. 2

Equity of a company. Several differences of opinion above then make the author interested in doing research on capital structure associated with the use of Debt and Equity to the Profitability of the company, related measurement variables The capital structure taken by researchers is the Debt To Equity Ratio company in the field of fisheries which is a growing industry along with human life.

Fisheries are all individual businesses or legal entities to catch or cultivate (hatchery, breeding, enlarging) fish, including storing, cooling, drying, or preserving fish in order to create economic added value for business actors.

Indonesia as the largest archipelagic country in the world has a sea of about 5.8 million $\mathrm{km}^{2}$ and according to World Resources Institute in 1998 it has $91,181 \mathrm{~km}$ of coastline in which contained fishery and marine resources. It gives a great potential to be used as the foundation of economic development based on source. Based on the latest data from the Central Bureau of Statistics (BPS), the fishery sector in Indonesia grew $8.37 \%$ on a year-on-year basis in the third quarter of 2015, much higher than the country's overall economic growth (at $4.73 \% \mathrm{y} / \mathrm{y}$ ) in the same quarter. Indonesia's fishery product exports reached 244.6 million US dollars in October 2015, while imports only reached 12.5 million US dollars (implying a trade surplus of 232.04 million US dollars). Generally, the world's cultivation fishery trends continue to increase, so the future of world fishery will be focused on the development of aquaculture. However, as in other economic sectors, this country has not utilized all the potential of the fishery sector and optimize profit.

From the three fishery companies listed on the IDX (Indonesia Stock Exchange), most have a poor profit and Profitability (ROE) that indicates a negative number. As seen below:

Table 1. Revenue and average of profitability fishery companies who listed in IDX from 2015 to 2016

\begin{tabular}{cccc}
\hline Year & Equity & Revenue & Profitability \\
\hline 2014 & $1,094,487,694,874$ & $-342,076,891,968$ & $-31 \%$ \\
2015 & $3,334,584,244,898$ & $-1,111,022,727,014$ & $-33 \%$ \\
2016 & $1,621,791,755,537$ & $-1,900,346,172,258$ & $-117 \%$ \\
\hline
\end{tabular}

Source: www.idx.co.id

From Table 1 it can be seen that the profit / loss gain of these companies after averaged negative results during the year 2014 to 2016. The biggest loss rate occurred in 2016 which amounted to $117 \%$.The highest loss rate experienced by the company PT. Central Proteina Prima, Tbk which continues to experience losses every year and the largest loss rate occurred in 2016 amounting to Rp. 1,997,038,000,000. And the capital structure of the firms under study, is calculated over five periods (2014 - 2016). As seen in Table 2 below: 


\section{$\triangle$ Macrothink}

International Journal of Accounting and Financial Reporting

Table 2. Capital structure of fishery companies that listed in IDX

\begin{tabular}{lccc}
\hline \multicolumn{1}{c}{ Company } & Equity & Total Debt & DER \\
\hline $\begin{array}{l}\text { PT. Central Proteina } \\
\text { Prima, Tbk }\end{array}$ & $3,080,983,000,000$ & $20,414,993,000,000$ & 6,62 \\
PT. Dua Putra Utama & $2,558,016,518,089$ & $984,535,324,989$ & 0,38 \\
$\begin{array}{l}\text { Makmur, Tbk } \\
\text { PT. Dharma }\end{array}$ & $411,864,177,220$ & $490,172,439,812$ & 1,19 \\
Samudera Fishing & & & \\
Industries, Tbk & & & \\
\hline
\end{tabular}

Source: www.idx.co.id

From the table above, it shows that the capital structure of fishery companies is fluctuating. The total debt of companies is much greater than the equity in terms of profit. In fact, a good company tends to have the amount of equity or capital itself is much larger than the debt. The previous table data shows that the return on equity indicated by profitability ratios clearly indicates a low and negative. When attributed in the opinion of Weston and Bringham (1994: 150) which states that companies that have low returns (investment profitability) tend to have large debts due to the use of equity (Own capital) is smaller.

This opinion is similar to the Sartono (1996: 296) who states that the greater the use of debt in the capital structure of the increasing ROE of a company. However, there are also several different opinions that the company could increase the profit is managing the funds efficienlty. According to Irawati (2006: 193) states that the use of each type of capital has a different effect on the profits derived by the company. while according to Aditya (2006: 22) states that Companies with high Profitability and greater use of internal financing can reduce the use of debt.

That condition happens due to company policies may change. Similarly, in determining the capital structure. It is tailored to the conditions and needs of the company. however, the company should be able to determine the optimal proportion of capital structure that can minimize costs and maximize Returns received. This can be one of the points for a company's performance that maximizes company value. Based on the description above, then make the author interested to do research about the effect of capital structure on profitability at fishery companies listed on the BEI (2014 - 2016.) This study aims to Analyze the influence of capital structure of Debt to Equity Ratio (DER) to Return On Equity ROE) on Fishery Companies listed on the Stock Exchange.

\section{Research Method}

The population in this research are three fishery companies with capital structure and Profitability of fishery company listed in Indonesia Stock Exchange. Whereas the sample selection method used is Purposive Sampling. Purposive Sampling is a technique of sampling the source of data with certain considerations. This particular purpose is to find out how 
much influence the capital structure of the company's profitability from the financial statements of fishery companies 2014 - 2016.

The sample in this research is the data of financial statements of three fishery companies listed on the BEI period from 2014 to 2016. The use of samples from 2014 to 2016 due to sufficient data sufficient to perform calculations on capital structure and profitability in fishery companies listed on BEI. In addition, during that period, fishery companies listed on the BEI experienced significant changes in their capital structure. So the data in that year represent the phenomenon to be studied.

Sugiyono (2007: 31) states that research variables are basically something that shaped what is determined by the researcher to be studied so that obtained information about it. The independent variable in this research is the capital structure measured by the Debt To Equity ratio of companies engaged in the fishery sector period 2014-2016. The dependent variables used in this study are Profitability as measured by Return On Equity companies that moving in fishery sector period 2014-2016

Data collection methods used in this study is the documentation. This method archives by researching and studying relevant document to the interests of research. It commonly referred to as Research Library, this method implement by reviewing the literature of various literature of scientific papers, magazines, and books relating to theories relevant to the issues discussed. The data used in this research is the time series data. Data publication of financial statements obtained from the BEI website (www.idx.co.id). Or more details about the types and sources of data related research is on the following points.

\section{Result and Discussion}

The following table shows the capital structure and profitability along with the Ratios that become the measurement variables in this study to see the influence on the fishery sector companies listed on the BEI period 2014- 2016:

Table 3. Capital structure and profitability of PT Centra Proteina Prima

\begin{tabular}{ccccccc}
\hline Year & Assets & Equity & Debt & Net profit & $\begin{array}{c}\text { DER } \\
(\boldsymbol{\%})\end{array}$ & $\begin{array}{c}\text { ROE } \\
(\boldsymbol{\%})\end{array}$ \\
\hline 2014 & $7,086,117$ & 917,715 & $6,168,402$ & $-389,907$ & 6.72 & -0.42 \\
2015 & $9,086,586$ & $1,982,383$ & $7,104,203$ & $-1,202,431$ & 3.58 & -0.61 \\
2016 & $7,323,273$ & 180,885 & $7,142,388$ & $-1,997,038$ & 39.48 & -11.04 \\
\hline
\end{tabular}

Source: www.idx.co.id

Capital structure at PT. Central Proteina Prima Tbk fluctuates every year. This is because the composition of different funding companies each year. The highest capital structure (DER) was obtained in 2016 at 39.48 (3948\%) and the smallest in 2015, where DER was only 3.58 $(358 \%)$, while the debt was larger than equity, reflecting the company preferring funding 
from outside of the company compared to their own capital, while for profitability, the company's net profit every year always suffered losses and fluctuated. As seen in 2016 where the company suffered loss of Rp 1,997,038,000,000, this means the company suffered losses increased in the year previously amounted to $\mathrm{Rp} 1,202,431,000,000$ in 2015 . This has an impact on the ratio of ROE that decreased compared to the year 2014 worth -0.42 or $42 \%$. The largest decline in 2016 as well as the smallest ROE ratio is worth - 11.04 or about $1104 \%$.

Table 4. Capital structure and profitability of PT. Dua Putra Utama Makmur Tbk

\begin{tabular}{ccccccc}
\hline Tahun & Aktiva & Ekuitas & Debt & $\begin{array}{c}\text { Laba } \\
\text { Bersih }\end{array}$ & $\begin{array}{c}\text { DER } \\
(\boldsymbol{\%})\end{array}$ & $\begin{array}{c}\text { ROE } \\
(\boldsymbol{\%})\end{array}$ \\
\hline 2014 & 310,943 & 56,916 & 254,027 & 35,955 & 4.46 & 0.63 \\
2015 & $1,575,468$ & $1,209,095$ & 336,461 & 77,867 & 0.28 & 0.06 \\
2016 & $1,686,051$ & $1,292,004$ & 394,047 & 90,940 & 0.30 & 0.07 \\
\hline
\end{tabular}

Source: www.idx.co.id

Capital structure at PT. Dua Putra Utama Makmur experience fluctuation. This is seen from the composition of debt that changes in each year, the largest debt composition occurs in 2016 worth Rp. 394.047.000.000,00 but for equity composition always experienced a significant increase. The largest DER ratio occurs in 2014 at 4.46 or $446 \%$ and the smallest in 2015 is 0.28 or $28 \%$. This illustrates that the company prefers funding from within the company ie own capital than from outside the company. So the profitability of the company's net profit continues to increase from 2014 to 2016. The ratio of the smallest ROE is 0.06 or $6 \%$ and the largest ROE ratio occurs in 2014 that is 0.63 or $63 \%$.

Table 5. Capital structure and profitability of PT. Dharma Samudera Fishing Industries, Tbk

\begin{tabular}{ccccccc}
\hline Tahun & Aktiva & Ekuitas & Debt & $\begin{array}{c}\text { Laba } \\
\text { Bersih }\end{array}$ & $\begin{array}{c}\text { DER } \\
(\boldsymbol{\%})\end{array}$ & $\begin{array}{c}\text { ROE } \\
(\boldsymbol{\%})\end{array}$ \\
\hline 2014 & 270,783 & 119,857 & 150,926 & 11,874 & 1.26 & 0.10 \\
2015 & 302,252 & 143,105 & 159,148 & 13,541 & 1.11 & 0.09 \\
2016 & 328,715 & 148,901 & 179,812 & 5,750 & 1.21 & 0.04 \\
\hline
\end{tabular}

Source: www.idx.co.id

Based on the financial ratio data in the tables above, then the following in Table 6 will be displayed Description of the research object. This study include: number of observations $(\mathrm{N})$, average, maximum value, minimum value and standard deviation for each variable. 


\section{Mll Macrothink}

International Journal of Accounting and Financial Reporting

ISSN 2162-3082

Table 6. Variables Description 2018, Vol. 8, No. 2

\begin{tabular}{lrrrrr}
\multicolumn{7}{c}{ Descriptive Statistics } \\
\hline DER & N & Minimum & Maximum & Mean & Std. Deviation \\
ROE & 9 & .28 & 39.48 & 6.4889 & 12.56005 \\
Valid N (listwise) & 9 & -11.04 & .63 & -1.2311 & 3.69484 \\
\hline
\end{tabular}

Sumber: Output SPSS 16

In Table 6 above shows that the amount of data used in this study as many as 9 samples of data taken from the annual financial report of fishery companies listed on the Indonesia Stock Exchange period 2014 - 2016.

Based on the calculation it appears that the average DER shows a high deviation, because the standard deviation value is much higher than Mean. Whereas, the average DER during observation period (2014-2016) of 6.4889 with standard deviation (SD) of 12.56005 hasi it shows that the SD values are greater than the average DER, which indicates that the DER variable data indicates poor results, because the standard deviation reflecting the deviation from the variable data is quite high because it is larger than the average.

The similar condition also hapen for ROE, where the average ROE during the observation period (2014-2016) is -1.2311 with the standard deviation (SD) of 3.69484. Though these two variables also show a smaller minimum value than the larger maximum value (indicated negative results at minimum values).

The maximum value of DER is 39.48, it experienced by PT. Central Proteina Prima Tbk in 2010. Meanwhile, for DER, the minimum value of 0.28 obtained by PT. Dua Putra Utama Makmur Tbk in 2015. The lowest ROE experienced by PT. Central Proteina Prima Tbk in 2016 with a minimum value of -11.04 . And the maximum value of 0.63 is experienced by PT. Dua Putra Utama Makmur Tbk in 2014. Both variables are DER and ROE indicate the less good.

\section{T test}

The $t$ test is intended to determine whether there is a partial influence of the variable (DER) on the dependent variable (ROE). while the partial effect of these independent variables on ROE is shown in table 7 below:

Table 7. $\mathrm{t}$ test

\section{Coefficients $^{\mathbf{a}}$}

\begin{tabular}{|c|c|c|c|c|c|c|}
\hline \multirow{2}{*}{\multicolumn{2}{|c|}{ Model }} & \multicolumn{2}{|c|}{$\begin{array}{l}\text { Unstandardized } \\
\text { Coefficients }\end{array}$} & \multirow{2}{*}{$\begin{array}{c}\text { Standardized } \\
\text { Coefficients } \\
\text { Beta }\end{array}$} & \multirow[t]{2}{*}{$\mathrm{T}$} & \multirow[t]{2}{*}{ Sig. } \\
\hline & & B & Std. Error & & & \\
\hline \multirow{2}{*}{1} & (Constant) & .650 & .255 & & 2.545 & .038 \\
\hline & DER & -.290 & .019 & -.985 & -15.325 & .000 \\
\hline
\end{tabular}

a. Dependent Variable: ROE

Sumber: Output SPSS 16 


\section{Mll Macrothink}

International Journal of Accounting and Financial Reporting

ISSN 2162-3082

The effect of DER variable on ROE can be seen from the direction of sign and level of significance. DER variable shows negative influence. DER variable has significant effect to ROE because significant value $<0.05$. The result of partial test ( $t$ test) between DER variable with ROE variable shows $t$ value equal to -15.325 and regression coefficient is $-0,290$, it means that DER have negative significant effect to ROE of Fishery Company in IDX. A probability value of 0.000 is smaller than 0.05 , meaning DER has significant effect on ROE. There is significantly influence between capital structure towards profitability.

\section{Goodness of Fit (F test)}

The F test basically shows whether all the independent variables have a mutual influence on the dependent variable. The results of calculation Test $\mathrm{F}$ this can be seen in Table 8 below:

Table 8. F test

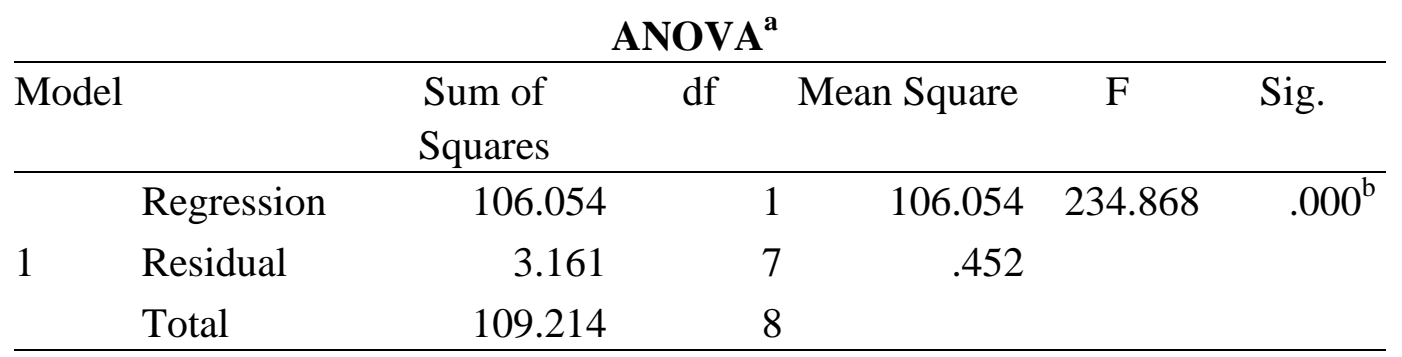

a. Dependent Variable: ROE

b. Predictors: (Constant), DER

Source: Output SPSS 16

The calculation results show that $\mathrm{F}$ value is 234.868 and a significant value is 0.00 . Because the significant value is less than 0.05 the hypothesis is accepted and there is a significant effect of DER variable on ROE. There is asignificant influence between capital structure towards profitability.

\section{Uji Koefisien Determinasi $\left(\mathbf{R}^{2}\right)$}

The coefficient of determination (R2) essentially measures how far the model's ability to explain the variation of its dependent variable. The value of the coefficient of determination (R2) approaching one means the independent variables explain almost all the information needed to predict the dependent variable (Ghozali, 2005). The results of calculation can be seen in Table 9 below: 


\section{Al Macrothink \\ International Journal of Accounting and Financial Reporting

Table 9. Determination coefficient measurement

\begin{tabular}{lrrrr}
\multicolumn{5}{c}{ Model Summary $^{\mathbf{b}}$} \\
\hline Model & R & R Square & $\begin{array}{c}\text { Adjusted R } \\
\text { Square }\end{array}$ & $\begin{array}{l}\text { Std. Error of } \\
\text { the Estimate }\end{array}$ \\
\hline 1 & $.985^{\mathrm{a}}$ & .971 & .967 & .67197 \\
\hline
\end{tabular}

a. Predictors: (Constant), DER

b. Dependent Variable: ROE

Sumber: Output SPSS 16

Based on the SPSS output it appears that from the calculation results obtained the coefficient of determination (R2) of 0.971 . In other words this shows that the relationship of DER variable to ROE is very strong with a percentage of $97.1 \%$, while the rest of $2.9 \%$ is explained by other variables outside the model.

\section{Simple regression analysis}

After performing the classical assumption test where to meet the normality test, the dependent variable data and independent variables. Then the linear regression equation in this study changed to: $\mathrm{Y}=\mathrm{a}+\mathrm{b} \mathrm{X}+\mathrm{e}$

Where:

$$
\begin{aligned}
& \mathrm{Y}=\text { Profitability (Return on Equity) } \\
& \mathrm{a}=\text { Constants } \\
& \mathrm{X}=\text { capital structure } \\
& \mathrm{b}=\text { Regression Coefficient The independent variable } \\
& \mathrm{e}=\text { error of term }
\end{aligned}
$$

\begin{tabular}{|c|c|c|c|c|c|c|}
\hline \multirow{2}{*}{\multicolumn{2}{|c|}{ Model }} & \multicolumn{2}{|c|}{$\begin{array}{l}\text { Unstandardized } \\
\text { Coefficients }\end{array}$} & $\begin{array}{l}\text { Standardized } \\
\text { Coefficients }\end{array}$ & \multirow[t]{2}{*}{$\mathrm{t}$} & \multirow[t]{2}{*}{ Sig. } \\
\hline & & $\mathrm{B}$ & Std. Error & Beta & & \\
\hline \multirow{2}{*}{1} & (Constant) & .650 & .255 & & 2.545 & .038 \\
\hline & DER & -.290 & .019 & -.985 & -15.325 & .000 \\
\hline
\end{tabular}

To find this linear regression equation, the author uses SPSS Version 16 and the results obtained from the data processing are as follows:

Table 10. Regression analysis

\section{Coefficients $^{\mathrm{a}}$}

a. Dependent Variable: ROE

Sumber: Output SPSS 16 


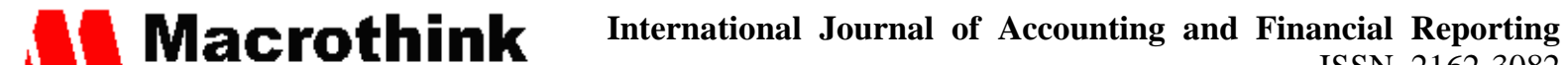

The regression equation as follows:

$$
\mathrm{Y}=0,650-0,290 \mathrm{X} \text { atau } \mathrm{ROE}=0,650-0,290 \text { DER }
$$

From the equation above, it can be seen that the constant value of 0.650 means that if $\mathrm{X}$ (capital structure) is considered constant (zero), then Y (ROE) will be worth 0.650. This shows that ROE has a value of 0.650 if the independent variable DER is considered constant. And the capital structure (X) has a regression coefficient of -0.290 . This means that if the capital structure increased by Rp. 1.00 then the DER will also increase with a negative ratio of -0.290 . The measurement of the capital structure as measured by the DER ratio of the fishery companies shows that DERs in those companies fluctuate from year to year.

Based on the relevant theory, the capital structure has a positive and significant influence on the profitability of the Fishery company. But based on the facts in the field, it turns out there is a negative and significant influence DER on the ROE of fisheries companies. Regression coefficient value of DER variable equal to -0.290 means that any effort of addition of one for DER ratio then there will be decrease ability to earn profit equal to 0,290.

The decline is caused by several things. First, from 2014 to 2016, there are companies that have a total equity of less than total liabilities. So it affects the high DER ratio, while the company's profit and ROE ratio shows the negative number. This means that each addition of DER ratio, then the ability to earn corporate profits will further decline. Secondly, since the period 2014 - 2016, there are companies that become the sample of this study suffered a loss so that the ratio of ROE shows the results tend to be negative each year. Though the company has a debt composition that always increases each year.

This is not in line with the opinion of Sartono (1996: 296) which states that the greater use of debt in the capital structure increases the ROE of the firm. Third, then even though the ROE ratio then improves because of the profit earned, the total equity is always lower than the total liabilities, then in this case the composition between debt and own capital in funding the company is very unbalanced. So the results of this study more in accordance with the opinion Irawati (2006: 193) which states that "the use of each - each type of capital has a different effect on the profits derived company. Fourth, from 2014 to 2016, the DER ratio always shows a greater percentage of the ROE, the higher the DER shows the composition of total debt is greater than the total capital itself, resulting in greater impact on the outside company (creditor). Increased burden on creditors shows the source of corporate capital is very dependent on outsiders and the amount of debt burden can reduce the amount of profit received by the company.

\section{Conclusion}

1. The result of model feasibility test of capital structure variable consisting of debt to equity ratio (DER) has significant negative effect to return on equity (ROE) with probability value $=0,0000<0,05$, mean DER have significant influence to ROE so that model worthy of being used as a partial test 


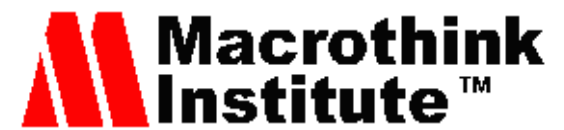

International Journal of Accounting and Financial Reporting

ISSN 2162-3082

2. The result of test of coefficient of determination R2, on capital structure variable consisting of debt to equity ratio (DER), to profitability (return on equity (ROE)) have very big, this can be seen from result of calculation obtained from coefficient of determination equal to $97.1 \%$, while the remaining $2.9 \%$ is explained by other factors not included in this study.

\section{Suggestion}

1. For the company after observing and analyzing the results of research, the authors see there are some things that can be used as input for practitioners and companies Fisheries. Researchers suggest that fishery companies sampled in this study to be more strict in considering the decision to make financing associated with financial leverage in this case the debt, the company needs to consider the effectiveness and efficiency of the debt in making profit for the company, because like that it has been discussed earlier that there will always be a trade-off between return and risk for firms, where the addition of debt in addition to helping finance for the company but also on the other hand will increase the risk level of the company.

2. For Further Researcher is expected to further researcher to further investigate this problem in depth. Use of Profitability Ratio can also use other variables such as Return On Assets (ROA) and Earning Per Share (EPS). Return On Assets (ROA) is used to assess the company's ability to generate profits by using assets owned by the company so that the efficiency and effectiveness of the overall assets used in the company's operations can be measured. Earning Per Share (EPS) is also used to determine earnings per share, so that shareholders can perform an analysis of the returns from per share owned in the future.

\section{References}

Aditya, J. (2006). Studi Empiris Faktor-Faktor yang Mempengaruhi Struktur Modal pada Perusahaan Manufaktur di Bursa Efek Jakarta Periode Tahun 2000- 2003. Skripsi. Universitas Islam Indonesia. Yogyakarta.

Agnes Sawir. (2005). Analisis Kinerja Keuangan dan Perencanaan Keuangan Perusahaan. PT Gramedia Pustaka, Jakarta.

Agus D. Harjito, Martono. (2002). Manajemen Keuangan. Edisi Pertama. Yogyakarta.

Agus Sartono. (2001). Manajemen Keuangan Teori dan Aplikasi. Yogyakarta: BPEF-YOGYAKARTA.

Aurin, Apriani. (2001). Analisis pengaruh struktur modal terhadap kinerja keuangan.Bandung: Universitas Padjajaran.

Bambang, Riyanto, (2001). Dasar-Dasar Pembelanjaan Perusahaan, Edisi Keempat, Cetakan Ketujuh, BPFE Yogyakarta, Yogyakarta.

Brigham, E. F., \& Weston, J. F. (2005). Dasar-Dasar Manajemen Keuangan, Edisi Kesembilan, Jilid 2, Penerbit Erlangga, Jakarta. 


\section{MInstitute ${ }^{\text {Macrothink }}$}

International Journal of Accounting and Financial Reporting

ISSN 2162-3082

Brigham, Eugene F. dan Gapenski, Louis C. (1997). Financial Management Theory and Practice. Orlando: The Dryden Press Brigham, Eugene F. dan Houston, Joel F. 2001. Manajemen Keuangan. Jakarta: Erlangga Brigham, Eugene F. dan Houston, Joel F. 2011 . Dasar-Dasar Manajemen Keuangan. 2011. Jakarta: Salemba 4.

Damodaran, Aswath. (1997). Corporate Finance, Theory and Practice. John Wiley \& Sons, Inc, USA.

Ghozali, Imam. (2011). Aplikasi Analisis Multivariate Dengan Program SPSS. Semarang: Badan Penerbit Universitas Diponegoro.

Irawati, Susan. (2006). Manajemen Keuangan. Cetakan Kesatu. Bandung: PT. Pustaka.

Kurniasih, Dwi Astuti dkk. (2015). Pengaruh Ukuran Perusahaan dan Profitabilitas Terhadap Corporate Social Responsibility Disclosure pada Perusahaan Manufaktur Sub Sektor Kimia yang Terdaftar di BEI Periode 116 2009-2013. Malang: Jurnal Konferensi Regional Akuntansi (KRA) II Tahun 2015 Jawa Timur.

Meidera Elsa Dwi Putri. (2012, September). Pengaruh Profitabilitas,Struktur Aktiva dan Ukuran Perusahaan terhadap Struktur Modal pada Perusahaam Manufaktur Sektor Industri Makanan dan Minyman yang Terdaftar di Bursa Efek Indonesia (BEI). Jurnal Manajemen, 1.

Myers, M. (1997). Qualitative Research in Information Systems. MIS Quarterly.

Sartono. (1996). Obat-obat Bebas Dan Bebas Terbatas. Jakarta: Penerbit PT.Gramedia Pustaka Utama. Halaman, 6, 8.

Sugiyono. (2014). Metode Penelitian Kuantitatif, kualitatif, dan R\&D. Bandung: Penerbit Alfabeta. Arikunto, S. (2009). Manajemenn Penelitian. Jakarta: Rineka Cipta.

Susan Irawati. (2006). Manajemen Keuangan. Pustaka: Bandung.

Sutrisno. (2003). Manajemen Keuangan Teori, Konsep, dan Aplikasi. Yogyakarta: Ekonosia www.idx.co.id

www.jcx.com

www.yahoo_finance.com

\section{Copyright Disclaimer}

Copyright for this article is retained by the author(s), with first publication rights granted to the journal.

This is an open-access article distributed under the terms and conditions of the Creative Commons Attribution license (http://creativecommons.org/licenses/by/4.0/) 